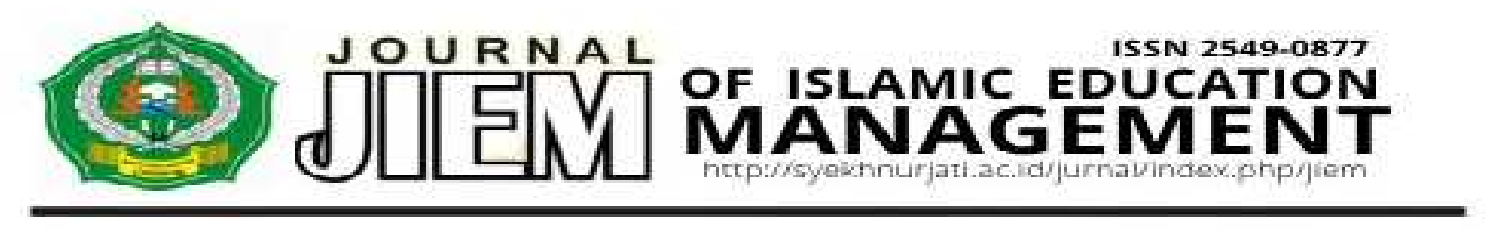

\title{
Pemanfaatan Education Management Information System (EMIS) dalam Pengambilan Keputusan di Seksi PAI Kementerian Agama Kabupaten Majalengka, Jawa Barat
}

\author{
Samsuri \\ Pendidik PAI di SMUN 1 Leuwimunding, Majalengka \\ E-mail : samsuri_1975@gmail.com
}

\begin{abstract}
Abstrak
Penelitian ini bertujuan untuk mengetahui pemanfaatan Sistem Informasi Manajemen Pendidikan (EMIS) dalam pengambilan keputusan di Seksi PAIS Kementerian Agama Kabupaten Majalengka Provinsi Jawa Barat. Penelitian ini merupakan penelitian kualitatif, teknik pengumpulan data dengan observasi, wawancara, dan dokumentasi. Hasil penelitian menunjukkan pertama, pengelolaan data dalam Sistem Informasi Manajemen Pendidikan meliputi pengumpulan melalui Forum Tenaga Kerja Guru, pokja guru, dan forum Guru Mata Pelajaran. Validasi data dilakukan oleh operator Sistem Informasi Manajemen Pendidikan di kabupaten kemudian diunggah ke dalam aplikasi online, penyimpanan data Sistem Informasi Manajemen Pendidikan disusun dalam bentuk excel. Kedua, pengambilan keputusan dilakukan dengan empat tahap: 1) identifikasi masalah, 2) menentukan alternatif solusi, 3. implementasi kebijakan, 4) evaluasi kebijakan. Ketiga, penggunaan Sistem Informasi Manajemen Pendidikan sebagai informasi dalam pengambilan keputusan telah dilakukan sesuai dengan tujuan penerapan Informador Manajemen Pendidikan. Sistem sebagai informasi di Kementerian Agama sebagai pusat data dan informasi pendidikan.
\end{abstract}

Kata Kunci : Sistem Informasi Manajemen Pendidikan, Pengambilan Keputusan

\section{Abstract}

This study aims to determine the use of the Education Management Information System (EMIS) in decision making in the PAIS Section of the Ministry of Religion, Majalengka Regency, West Java Province. This research is a qualitative research, data collection techniques with observation, interviews, and documentation. The results of the study show that first, data management in the Education Management Information System includes collection through the Teacher Workforce Forum, teacher working groups, and Subject Teacher forums. Data validation is carried out by the Education Management Information System operator in the district then uploaded into an online application, the Education Management Information System data storage is compiled in excel form. Second, decision making is carried out in four stages: 1) problem identification, 2) determining alternative solutions, 3. policy implementation, 4) policy evaluation. Third, the use of the Education Management Information System as information in decision making has been carried out in 
accordance with the objectives of implementing the Education Management Information

System. The system as information in the Ministry of Religion as a data center and education information.

\section{Keywords: Education Management Information System, Decision Making}

\section{A. Pendahuluan}

Sistem informasi manajemen merupakan kebutuhan yang diperlukan dalam suatu organisasi untuk mencapai efektifitas dan efisensi kerja khususnya dalam era perkembangan teknologi seperti saat ini. Salah satu manfaat dari sistem informasi manajemen dalam organisasi adalah sebagai sarana pengambilan keputusan. Administrasi pada hakikatnya adalah pengambian keputusan. Karena setiap kegiatan di dalam organisasi pasti terdapat permasalahan yang harus diselesaikan, baik dengan cara demokratis maupun menggunakan otoritas pimpinan. Keputusan yang baik memerlukan pemahaman tentang masalah dan pengetahuan tentang alternatif pemecahannya. "Ketepatan dan keakuratan yang baik akan mempengaruhi pengambilan keputusan yang baik pula. Oleh karena itu pemanfaatan sistem informasi manajemen sangatlah penting agar kebijakan yang diambil sesuai dengan kebutuhan yang didasarkan pada data yang tepat dan akurat.

Merupakan suatu langkah maju bagi perkembangan manajemen khususnya bidang Pendidikan Islam telah mempunyai sistem informasi manajemen yang dirancang dan dikembangkan oleh Direktorat Jenderal Kelembagaan Agama Islam yang dikenal sebagai EMIS (Education Management Information System). Perancangan dan pengembangan EMIS diharapkan dapat dijadikan sebagai penyedia data dan informasi yang dibutuhkan dalam perumusan kebijakan, penyusunan anggaran, pengambilan keputusan, perencanaan penyelenggaraan pendidikan, dan pengembangan pendidikan agama.

EMIS dirancang untuk mengatur data dan informasi dalam skala besar yang kemudian dapat dibaca, diambil kembali, diproses, dianalisis dan disajikan untuk digunakan dan disebarkan. Seksi Pendidikan Agama Islam merupakan salah satu seksi dalam jajaran organisasi Kementerian Agama Kabupaten Majalengka yang memiliki tugas melakukan pelayanan dan bimbingan teknis, pembinaan serta pengelolaan data dan informasi di bidang Pendidikan Agama Islam pada PAUD, SD / SDLB, SMP / SMPIB, SMA / SMALB / SMK. Dalam praktik pengelolaan data dan informasinya, seksi ini dibantu oleh beberapa orang staf yang salah satunya memiliki tanggung jawab khusus dalam pengelolaan data base dan pendataan EMIS tersebut.

Data EMIS diperbaharui secara berkala setiap semester. Hal ini bertujuan agar dapat memperoleh informasi-informasi terbaru sehingga mempermudah kepala seksi dalam mengontrol dan menganalisis informasi sebagai bahan pengambilan keputusan. Adapun kendala yang dihadapi oleh seksi PAI dalam mengumpulkan data EMIS saat ini adalah pengumpulan data dari beberapa guru agama yang kurang menganggap penting data EMIS sehingga mereka tidak melengkapi data EMIS tepat waktu. Hal ini menyebabkan keterlambatan terkumpulnya data dari jadwal yang telah ditentukan.

Pengambilan keputusan adalah suatu hal yang penting dalam organisasi. Sedangkan informasi merupakan komponen pokok yang dibutuhkan seorang pemimpin dalam 
pengambilan keputusan. Ketepatan dan keakuratan informasi ${ }^{i}$ ang diperoleh dapat mempengaruhi kualitas keputusan yang diambil.

Dari pemaparan di atas, penelitian akan menganalisis pemanfaatan EMIS bagai Sarana Pengambilan Keputusan di Seksi PAI Kementerian Agama Kabupaten Majalengka yang berfokus kepada tiga uraian permasalahan pokok, yaitu bagaimana pengelolaan data EMIS, proses pengambilan keputusan, dan pemanfaatan data EMIS dalam pengambilan keputusan di seksi PAI Kementerian Agama Kabupaten Majalengka.

\section{B. Sistem Informasi Manajemen Pendidikan}

Sistem informasi ialah kombinasi terorganisasi apapun dari manusia, perangkat keras, perangkat lunak, jaringan komunikasi, sumber data, dan kebijakan serta prosedur yang terorganisasi yang menyimpan, mengambil, mengubah, dan memisahkan informasi dalam sebuah organisasi (James A. O Brien dan George M. Marakas, 2014:4). Menurut Wahyu Winarno (2004:16), sistem informasi sekumpulan komponen yang saling bekerja sama, yang digunakan untuk mencatat data, mengolah data, dan menyajikan informasi untuk para pembuat keputusan agar dapat membuat keputusan dengan baik.

Sistem informasi manajemen adalah suatu sistem yang dirancang untuk menyediakan informasi guna mendukung pengambilan keputusan pada kegiatan manajemen dalam suatu organisasi. O'Brien dalam Rusdiana (2014:94-95), menjelaskan bahwa sistem informasi manajemen adalah sistem terpadu yang menyediakan informasi untuk mendukung kegiatan operasional, manajemen, dan fungsi pengambilan keputusan dari suatu organisasi. Fuadi Aziz mendefinisikan sistem informasi manajemen adalah sebuah sistem berbasis komputer yang digunakan untuk menyediakan berbagai informasi berbentuk data-data yang dapat digunakan sebagai dasar pengambilan keputusan organisasi.

Menurut Eti Rochaety dkk.(2009:13), bahwa sistem informasi manajemen pendidikan adalah perpaduan antara sumber daya manusia dan aplikasi teknologi informasi untuk memilih, menyimpan, mengolah, dan mengambil kembali data dalam rangka mendukung proses pengambilan keputusan bidang pendidikan.

Pengertian lain sistem informasi manajemen pendidikan adalah suatu sistem yang dirancang untuk menyediakan informasi guna mendukung pengambilan keputusan pada kegiatan manajemen (perencanaan, penggerakan, pengorganisasian, dan pengendalian) dalam lembaga pendidikan."

\section{Educational Management Information System (EMIS)}

EMIS merupakan suatu metode manajemen formal dalam penyediaan informasi pendidikan yang akurat dan tepat waktu sehingga proses pengambilan keputusan, perencanaan, pengembangan proyek dan fungsi-fungsi manajemen pendidikan lainnya dapat dilaksanakan secara efektif. EMIS adalah sekelompok informasi dan dokumentasi yang terorganisasi dalam melaksanakan pengumpulan, penyimpanan, pengolahan, analisis dan penyebaran informasi (data) yang digunakan untuk manajemen dan perencanaan pendidikan. Pengertian lain menyebutkan bahwa EMIS adalah sistem untuk mengatur data dan informasi pendidikan dalam jumlah besar yang dapat dibaca, diambil kembali, diproses, dianalisis dan disajikan untuk digunakan dan disebarkan (Dodi Irawan dan Rosidin, 2003:20).

Aplikasi Education Management Information System (EMIS) merupakan 
sistem informasi penunjang administrasi dan pendataan pendidikan agama yang ada di wilayah Kementerian Agama. Sistem ini dirintis ketika adanya proyek pinjaman luar negeri yang didanai dari Asian Development Bank (ADB) untuk proyek Peningkatan Mutu Pendidikan Lanjutan Pertama pada tahun 1994 -1998. Setelah proyek pertama tersebut berakhir, kemudian dilanjutkan dengan proyek Peningkatan Mutu Pendidikan Dasar dan proyek Pengembangan Madrasah Aliyah.

Kegiatan EMIS terus menerus menggunakan pendanaan dari ADB. Kemudian ketika mulai memasuki tahun anggaran 2001 hingga saat ini, pendanaan tersebut diambil alih sepenuhnya oleh pemerintah Republik Indonesai melalui dana Anggaran Pendapatan dan Belanja Negara (APBN).

\section{Pengambilan Keputusan}

Keputusan merupakan hasil proses pemikiran yang berupa pemilihan satu

E. Pengelolaan EMIS di seksi PAI Kemeterian Agama Kabupaten Majalengka Provinsi Jawa Barat

1. Penerapan EMIS di Seksi PAI Kementerian Agama Kabupaten

Majalengka

Aplikasi Education Management Information System (EMIS) merupakan sistem informasi penunjang administrasi dan pendataan pendidikan agama yang ada di wilayah Kementerian Agama. Sistem ini dirintis ketika adanya proyek pinjaman luar negeri yang didanai dari Asian Development Bank (ADB) untuk proyek Peningkatan Mutu Pendidikan Lanjutan Pertama pada tahun 1994 - 1998. Setelah proyek pertama tersebut berakhir, kemudian dilanjutkan dengan proyek Peningkatan Mutu Pendidikan Dasar dan proyek Pengembangan Madrasah Aliyah. Kegiatan EMIS terus menerus diantara beberapa alternatif yang dapat digunakan untuk memecahkan masalah yang dihadapi. Menurut Ralp C. Davis, Marry Follet, dan James A.F. Stoner dalam Hamdan Dimyati (2014289), bahwa keputusan adalah hasil pemecahan masalah yang didasari atas logika dan pertimbangan, penetapan alternatif terbaik, dan harus mendekati tujuan yang telah ditetapkan.

Pengambilan keputusan adalah suatu pendekatan yang sistematis terhadap hakekat suatu masalah, pengumpulan fakta-fakta dan data, penentuan alternatif yang dihadapi, dan mengambil tindakan yang paling tepat menurut perhitungan. ${ }^{16}$ Menurut Didin Kurniadin dan Imam Machali, pengambilan keputusan adalah sebuah proses pemilihan alternatif-alternatif keputusan dalam rangka menyelesaikan masalah yang dihadapi (Didin Kurnadin dan Imam Machali,2012:324).

menggunakan pendanaan dari ADB. Kemudian ketika mulai memasuki tahun anggaran 2001, pendanaan tersebut diambil alih sepenuhnya oleh pemerintah Republik Indonesai melalui dana Anggaran Pendapatan dan Belanja Negara (APBN).

EMIS dikelola serta diaplikasikan langsung oleh Direktorat Madrasah dan Pendidikan Agama Islam pada Sekolah Umum sesuai dengan kebutuhan. Dalam tingkat kabupaten, khususnya di Kementerian Agama Kabupaten Majalengka, EMIS dikelola dan diaplikasikan oleh seksi Madrasah dan Pendidikan Agama (MAPENDA) hingga tahun 2012. Berdasarkan Peraturan Menteri Agama (PMA) nomor 13 tahun 2012 tentang Organisasi dan Tata Kerja Instansi Vertikai Kementerian Agama, mulai tahun 2013 hingga saat ini MAPENDA telah digantikan dengan seksi Pendidikan Madrasah (DIKMAD) sebagai 
penanggung jawab pada pendidikan RA, MI, MTs, MA, dan MAK, serta seksi Pendidikan Agama Islam (PAIS) sebagai penanggung jawab dalam urusan pendidikan agama di sekolah umum. Adapun bunyi Peraturan Menteri Agama (PMA) nomor 13 tahun 2012 pasal 462 ayat 4 adalah sebagai berikut:

"Seksi Pendidikan Agama Islam sebagaimana dimaksud dalam Pasal 461 mempunyai tugas melakukan pelayanan dan bimbingan teknis, pembinaan serta pengelolaan data dan informasi di bidang pendidikan agama Islam pada PAUD, SD/SDLB, SMP/SMPLB, SMA/SMALB/SMK".

Oleh karena itu, aplikasi EMIS seksi Pendidikan Agama Islam dirancang dan diaplikasikan bersamaan dengan diterapkannya PMA nomor 13 tahun 2012 pada organisasi dan tata kerja tahun 2013. ${ }^{20}$ Didukung juga oleh Surat Edaran Direktur jenderal Pendidikan Islam tentang Kebijakan Pendataan Pendidikan Islam Satu Pintu melalui EMIS.

\section{Format Aplikasi EMIS di Seksi} PAI Kementerian Agama Kabupaten Majalengka

Aplikasi EMIS di seksi Pendidikan Agama Islam Kementerian Agama Kabupaten Majalengka pada dasarnya sama dengan aplikasi EMIS di seksi PAI dan Dikmad Kementerian Agama seluruh Indonesia. Awal mula diberlakukannya PMA no. 13 tahun 2012, aplikasi EMIS di seksi PAI hanya berupa aplikasi data dalam bentuk excel yang memuat kompleksitas data guru dan murid. Kemudian mulai semester genap tahun ajaran 2015/2016, diterapkan aplikasi EMIS berbasis online sebagai pengembangan dari aplikasi sebelumnya. Perbedaan antara aplikasi EMIS PAI dengan aplikasi EMIS Dikmad adalah terletak pada kompleksitas data yang dimuat, dikarenakan tugas pokok dan fungsi kedua seksi tersbut juga berbeda. Adapun aplikasi online antara PAI dan Dikmad mempunyai kesamaan pada alamat web yaitu http://emispendis.kemenag.go.id/.

Yang membedakan adalah EMIS Dikmad memuat lebih banyak data meliputi lulusan, siswa, lembaga / madrasah termasuk juga sarana dan prasarana, dan personal dalam lembaga yang meliputi guru, tata usaha, dan semua jajaran yang di madrasah. Sedangkan EMIS PAI hanya memuat data guru dan murid saja. Untuk masuk ke halaman web, para operator EMIS pada tiap-tiap seksi memiliki nama pengguna dan kata kunci yang sudah terdaftar sesuai dengan inya. Jadi jika masuk menggunakan kata kunci yang terdaftar di seksi PAI, aplikasi online akan langsung memunculkan halaman khusus untuk seksi PAl, begitu juga untuk seksi Dikmad.

Dalam hal ini peneliti memandang bahwa aplikasi EMIS merupakan aplikasi $\mathrm{s}^{\wedge}$ ang memuat data yang sangat kompleks sehingga dapat dijadikan pendukung informasi dalam pengambilan keputusan. Aplikasi EMIS juga tidak membutuhkan spesifikasi komputer yang tinggi meskipun terdiri dari dua aplikasi yang berbentuk excel dan berbasis online, karena pada dasarnya aplikasi excel dan online merupakan aplikasi ringan yang memuat data-data yang memiliki kapasitas mulai dari kilo bite hingga mega bite saja, sehingga dapat menghemat biaya untuk operasional komputer.

Pandangan ini juga didukung dengan hasil wawancara bahwa spesifikasi komputer di seksi PAI, serta didukung sistem operasi windows7 dinilai sudah dapat mengoperasikan aplikasi EMIS 
dengan lancar, tergantung dengan kekuatan signal internet yang digunakan.

\section{Pengumpulan Data EMIS di Seksi PAI Kementerian Agama Kabupaten Majalengka}

Tahap pengumpulan data EMIS di seksi PAI Kementerian Agama Kabupaten Majalengka dilakukan dengan mengoptimalkan kinerja Forum Komunikasi Guru (FKG) dari TK, Kelompok Kerja Guru (KKG) dari SD, dan Musyawarah Guru Mata Pelajaran (MGMP) dari SMP, SMA, dan SMK pada tiap-tiap kecamatan.

Operator EMIS membagikan angket kosong yang memuat seluruh data yang diperlukan untuk pengisian EMIS dalam format excel kepada para guru penanggung jawab tiap kecamatan baik berupa hard copy maupun melalui e-mail. Atau dapat juga para penanggung jawab tiap kecamatan mengunduh aplikasi format excel melalui web EMIS secara langsung.

Selanjutnya penanggung jawab tiap kecamatan mendata guru-guru PAI yang ada di kecamatan tersebut, kemudian dikumpulkan kembali ke seksi PAI untuk dimasukkan ke dalam aplikasi EMIS berformat excel di komputer pusat pendataan EMIS seksi PAI Kementerian Agama Kabupaten Majalengka.

Setelah semua data dimasukkan ke dalam aplikasi EMIS format excel, selanjutnya operator EMIS meneliti kembali data-data yang terkumpul untuk menghindari kesalahan teknis penulisan maupun kekosongan data pada sebagian kolom. Jika ada data yang masih kosong, maka operator mencari data tersebut dengan melihat kembali berkas-berkas hard copy yang ada, atau langsung menghubungi guru yang bersangkutan melalui telpon. Jika segala upaya sudah dilakukan, namun guru tersebut masih sulit untuk dimintai data, maka atas rekomendasi Kepala Seksi serta para nenanggung jawab tiap kecamatan, nama guru tersebut akan dihapus dari data EMIS online. Hal ini dikarenakan sistem aplikasi online akan secara otomatis menolak data yang masih terdapat kekosongan.

Tahap selanjutnya adalah validasi data melalui aplikasi dekstop. Aplikasi dekstop adalah aplikasi offline yang digunakan untuk validasi dan backup data dari format excel menjadi format EMIS.

Kemudian tahap terakhir adalah memasukkan hasil validasi dan backup data dengan format EMIS ke dalam aplikasi online melalui laman http:7/emispendis.kemenag. go.id/ dengan menggunakah nama pengguna dan kata kunci operator yang sudah terdaftar sebagai penanggung jawab dari seksi PAI.

Setelah seluruh data EMIS dimasukkan ke aplikasi online, maka datadata tersebut akan masuk ke server EMIS pusat yang dapat diakses, ditinjau, dan dievaluasi kembali oleh operator EMIS Kanwil maupun operator EMIS pusat.

Data EMIS disimpan dalam komputer server operator EMIS yang tersusun secara rapi berdasarkan tahun dan semester. Sehingga data EMIS mulai dari awal terbentuknya seksi PAI tahun 2013 hingga saat ini masih tersimpan rapi. Operator EMIS berencana untuk menyimpan semua data sampai tahuntahun yang akan datang sebagai dokumentasi. Bp. Tommy selaku operator EMIS menegaskan bahwa data EMIS akan terus disimpan karena kemungkinan rusaknya kecil, mudah ditata, dan tidak memakan banyak tempat. Berbeda dengan arsip yang berbentuk lembaran kertas yang hanya disimpan dalam jangka waktu lima tahun, kemudian dimusnahkan atau dipindahkan. 
Pembaruan data EMIS harus selalu dilakukan tiap awal semester, seksi PAI Kementerian Agama Kabupaten Majalengka memiliki inisiatif bahwa data EMIS harus sudah terkumpulkan seluruhnya dalam kurun waktu dua bulan terhitung sejak awal pembukaan semester baru. Hal ini bertujuan agar proses pengoreksian data dapat segera terselesaikan. Karena menurut Bp. Tommy, aplikasi EMIS berbasis online tidak akan menerima data yang terdapat kesalahan sedikitpun, baik dari kesalahan penulisan, kesalahan ejaan, kesalahan format, hingga kesalahan data itu sendiri.

"Kalau input data di tingkat kabupaten saat ini masih manual, satu per satu, nanti per kecamatan kita cek dulu satu per satu, untuk secara detilnya itu ketahuan bila dimasukkan ke aplikasi, soalnya di aplikasi itu kesalahan

sedikitpun ndak bisa masuk seperti karakter, penulisan besar kecil hurufnya dan lain sebagainya".

Adapun tahap pembaruan data EMIS sampai di tingkat Kemenag kabupaten terlebih dahulu melalui adanya informasi dari Kementerian Agama pusat, diteruskan kepada Kantor Wilayah Propinsi, kemudian diteruskan ke Kantor Kabupaten, dari kabupaten diteruskan langsung kepada guru-guru melalui penanggung jawab per kecamatan dari FKG, KKG, dan MGMP.

Menurut pandangan peneliti, proses pengumpulan data EMIS untuk saat ini masih membutuhkan banyak tenaga, disamping itu aplikasi EMIS masih terbagi menjadi dua. Sehingga perlu diadakan pengoreksian berulang-ulang terhadap data-data tersebut hingga memperoleh data yang akurat dan valid. Peneliti memandang bahwa jangka waktu pengumpulan dan pengoreksian data EMIS dalam satu semester masih kurang efisien jika dibandingkan dengan jangka waktu yang di tempuh dalam satu semester. Dapat diilustrasikan, jika satu semester terdiri dari empat atau lima bulan, sedangkan pengumpulan dan pengoreksian data membutuhkan waktu dua hingga tiga bulan, maka kurang lebih lima puluh persen waktu dalam satu semester telah dihabiskan untuk pembaruan dan validasi data EMIS. Sedangkan data EMIS harus diperbarui tiap awal semster. Jadi apabila terdapat suatu permasalahan yang muncul di awal bulan dalam satu semester tertentu, dan dalam pemecahan masalahnya membutuhkan informasi dari EMIS, maka data EMIS untuk satu semester tersebut belum bisa membantu memberikan informasi yang dibutuhkan kecuali melihat data EMIS semester sebelumnya. Hal ini dirasa masih belum sesuai dengan karakter sistem informasi yang baik yaitu dapat memberikan informasi yang akurat dan tepat waktu.

\section{Penyajian Data EMIS di Seksi PAI Kementerian Agama Kabupaten Majalengka}

Untuk memperoleh informasi yang akurat, diperlukan sarana penunjang yang memadai, seperti komputer dan software yang berfungsi secara normal. Selain itu, kemampuan penguasaan teknologi informasi bagi sumber daya manusia yang bertanggung jawab dalam menyediakan informasi juga harus mumpuni. Seksi PAI Kementerian Agama Kabupaten Majalengka memiliki operator khusus untuk mengoordinasi, menyimpan. mengolah, dan menyajikan data EMIS sehingga informasi EMIS dapat dengan mudah diakses oleh siapapun yang membutuhkan atas rekomendasi dari Kepala Seksi. Operator EMIS selalu 
mengikuti pelatihan-pelatihan pengoperasian EMIS yang diadakan oleh Kementerian Agama pusat maupun tingkat propinsi. Sehingga kemampuan mereka dalam mengelola data EMIS terus mengalami kemajuan.

Seksi PAI Kementerian Agama Kabupaten Majalengka tidak mempunyai kewenangan untuk merubah, mengurangi, atau menambah format aplikasi EMIS berbasis excel, dikarenakan format tersebut sudah paten dari Kementerian Agama pusat. Sedangkan kebutuhan data EMIS bagi organisasi internal Kementerian Agama khususnya seksi PAI bermacammacam. Sehingga untuk menyiasati hal ini, operator EMIS berinisiatif untuk membuat format terpisah dari aplikasi tersebut namun mengandung kompleksitas data yang sama. Hal ini bertujuan agar dapat memenuhi kebutuhan data bagi organisasi internal seksi PAI dalam menganalisis kebutuhan-kebutuhan bidang Pendidikan Agama Islam secara lebih terperinci. Dengan demikian, data EMIS dapat dirubah, ditambah, maupun dikurangi menyesuaikan dengan kebutuhan.

Format aplikasi EMIS yang masih manual, membutuhkan ketelitian dalam menyajikan informasi yang dibutuhkan. Hal ini disamping kompleksitas data EMIS yang cukup banyak, juga ketika ada yang membutuhkan informasi dari data EMIS, operator harus memilah satu per satu data yang dibutuhkan, kemudian memindahkannya secara manual ke format excel, setelah itu barulah data-data tersebut dapat dianalisis menjadi informasi untuk kebutuhan pengambilan keputusan.

Jadi informasi EMIS dapat disajikan dalam format yang sama yaitu excel tetapi dengan bentuk yang berbeda sesuai informasi apa saja yang diinginkan. Menurut analisis peneliti, menyajikan informasi EMIS bukanlah hal yang sederhana. Hal ini dikarenakan format aplikasi EMIS masih manual berupa excel yang memuat banyak kolom. Sehingga informasi akan dapat tersaji dengan akurat dan valid apabila operator EMIS lebih teliti dalam memilih data yang dibutuhkan untuk disajikan.

\section{Pengambilan Keputusan di Seksi PAI Kementerian Agama Kabupaten Majalengka}

Salah satu fungsi organisasi adalah untuk menyelesaikan permasalahan. Untuk mendapatkan sebuah keputusan atas masalah-masalah yang ada, suatu organisasi memerlukan seorang pemimpin.

Penyelesaian masalah di seksi PAI Kementerian Agama Kabupaten Majalengka dilakukan dengan mengutamakan metode pendekatan personal terhadap pihak-pihak yang berhubungan dengan permasalahan tersebut. Dengan ini diharapkan keputusan yang akan diambil bisa diterima oleh siapapun. Sehingga jika ada yang merasa keberatan, bisa langsung dimusyawarahkan kembali. Seperti yang diungkapkan oleh Kepala Seksi PAI Kementerian Agama Kabupaten Majalengka:

"Kita tidak menggunakan apa ya, kewenangan kebijakan saya, enggak, saya selalu menggunakan metode pendekatan, kalo saya tetep, yang namanya pendekatan itu mesti saya lakukan walaupun saya, ow ini langsung eksekusi, oh guru ini bermasalah, langsung saya pindah, katakanlah, enggak bisa, tetep saya selalu menggunakan pola-pola pendekatan itu". 
Proses pengambilan keputusan di seksi PAI kementerian Agama Kabupaten Majalengka dilakukan dengan beberapa tahap yang terdiri dari identifikasi masalah, perumusan alternatif pemecahan masalah, implementasi kebijakan, dan evaluasi.

Identifikasi masalah yang dilakukan oleh seksi PAI Kementerian Agama Kabupaten Majalengka adalah dengan cara terjun ke lapangan dalam rangka mengawasi dan mengontrol proses pendidikan khususnya Pendidikan Agama Islam yang ada di sekolah-sekolah umum dengan memanfaatkan kinerja pengawas. Dari kegiatan ini akan diperoleh permasalahan-permasalahan yang terjadi di lapangan seperti permasalahan tentang kompetensi guru maupun permasalahan tentang implementasi pembelajaran Pendidikan Agama Islam. Permasalahan tersebut segera diinfentarisasi oleh pengawas untuk dilaporkan ke seksi PAI agar mempermudah dalam menganaisis alternatif pemecahan masalahnya.

Proses selanjutnya adalah perumusan alternatif pemecahan masalah. Perumusan alternatif pemecahan masalah dilakukan dengan jalur diskusi dan musyawarah antara staf seksi PAI dan pengawas. Dalam hal ini Kepala Seksi PAI juga melibatkan pihak-pihak yang terkait dalam perumusan alternatif pemecahan masalahannya. Sehingga seksi PAI akan menerima berbagai macam usulan yang masuk dari pengawas, staf, maupun kepala sekolah yang bersangkutan sebagai pertimbangan alternatif pemecahan masalah yang kemudian disosialisakan kepada guru yang bersangkutan untuk mengambil tindakan yang tepat serta sesuai dengan aturan dan kemaslahatan bersama. Selain itu, Bp. Kepala Seksi PAI juga tidak luput untuk selalu meminta pertimbangan dari atasan agar senantiasa selalu mendapatkan solusi yang terbaik daiam pengambilan keputusan.

Setelah alternatif pemecahan masalah disosialisasikan kepada guru yang bersangkutan, selanjutnya guru tersebut diberikan solusi untuk pemecahan masalahnya. Seperti contoh dalam penerapan UU N0.14 tahun 2005 tentang guru dan dosen yang menyatakan bahwa kualifikasi dasar guru salah satunya adalah minimal harus Si. Batas pemberlakuan regulasi ini adalah per i Januari 2016, sedangkan di wilayah Kabupaten Majalengka terdapat seorang guru Sekolah Menengah Pertama (SMP) yang belum memenuhi kualifikasi tersebut. Sehingga setelah proses analisis yang dilakukan oleh seksi PAI Kementerian Agama Kabupaten Majalengka, diperolehlah keputusan sesuai aturan yang ada bahwa guru tersebut tidak dapat melanjutkan jabatan fungsionalnya sebagai guru. Sehingga guru tersebut harus dialihkan sebagai jabatan fungsional umum.

Dalam implementasi keputusan ini seksi PAI tidak berwenang untuk memindah tugaskan guru tersebut secara sepihak, melainkan memberikan solusi penyelesaiannya dengan meminta guru tersebut membuat surat pernyataan mengundurkan diri dari jabatannya sebagai guru, kemudian seksi PAI mengusulkan hal tersebut ke kepegawaian dan eselon untuk diterbitkan surat keputusan dan surat perintah tugas yang baru.

"prosesnya yang bersangkutan itu menyatakan e pengunduran diri. Jadi harus yang bersangkutan, kalo yang tidak ada pe permohonan dari yang bersangkutan tidak bisa, kami tidak bisa mengeksekusi. Dadi tetep alurnya karena yang bersankutan belum Si itu harus membuat pernyataan untuk mengundurkan 
diri, mutasi dari jabatan fungsional tertentu menjadi jabatan fungsional umum, barulah nanti kita, kita usulkan ke kepegawaian sampai di tingkat eselon, seperti itu".

Proses yang terakhir adalah evaluasi. Proses ini dilakukan dengan meninjau ulang implementasi keputusan yang telah diambil kepada guru yang bersangkutan. Evaluasi dilakukan terus-menerus tiap semester. Hal ini bertujuan untuk mengantisipasi adanya permasalahan baru yang timbul di lapangan.

Menurut pandangan peneliti, proses pengambilan keputusan di seksi PAI Kementerian Agama Kabupaten Majalengka secara garis besar sama dengan proses pengambilan keputusan pada umumnya. Namun yang menjadi kekuatan pengambilan keputusan yang dilakukan oleh seksi PAI adalah dalam menerapkan metode dan dasar pengambilan keputusannya. Dalam hal ini kepala seksi PAI selalu mengutamakan metode pendekatan personal, sehingga keputusan yang diambil dapat diterima oleh semua pihak.

Dasar pengambilan keputusan yang diterapkan dalam menjalankan tugas dan merumuskan kebijakan adalah komitmen terhadap aturan yang berlaku, sehingga jika ada aturan yang tegas maka harus ditegakkan. Namun jika muncul permasalahan yang bersifat teknis maka akan ditempuh dengan jalan musyawarah dan pendekatan

\section{Memanfaatkan Data EMIS untuk Pengambilan Keputusan di Seksi PAI Kementerian Agama Kabupaten Majalengka}

Sistem aplikasi EMIS di seksi PAI Kementerian Agama Kabupaten Majalengka merupakan sistem penyedia data yang diharapkan bisa memenuhi kebutuhan informasi sebagai bahan analisis dalam menentukan kebijakan. Kompleksitas data EMIS sudah cukup lengkap untuk memenuhi kebutuhan data pendidikan sebagai dasar pengambilan keputusan.

Pemanfaatan EMIS di seksi PAI Kementerian Agama Kabupaten Majalengka dapat terlihat dalam setiap proses pengambilan keputusan mulai dari identifikasi masalah hingga analisis alternatif pemecahan masalah. Kepala seksi PAI menegaskan bahwa data EMIS sangat membantu dalam pengambilan keputusan yang berkaitan dengan kebutuhan jumlah guru, pemerataan guru, pemenuhan jam mengajar guru, penentuan peserta sertifikasi guru, serta perencanaan anggaran pendidikan. ${ }^{31}$ Hal ini dikarenakan aplikasi EMIS dapat merekam data seperti rasio lembaga dan guru serta murid sehingga analisis data untuk pemenuhan kebutuhan pengambilan keputusan dapat terpenuhi.

Pada praktiknya, pengambilan keputusan di seksi PAI Kemeneterian Agama Kabupaten Majalengka tidak hanya bertumpu pada data EMIS saja, melainkan didukung dengan laporan-laporan dari pengawas, kepala sekolah, FKG, KKG, MGMP, serta laporan dari guru maupun dari sumber-sumber lain. Hal ini untuk memastikan bahwa data dan informasi yang digunakan sebagai pengambilan keputusan benar-benar data dan informasi yang tepat, akurat, dan dapat dipercaya.

Salah satu contoh pengambilan keputusan berbasis EMIS adalah dalam pemerataan atau pemenuhan jam mengajar guru. Jika suatu lembaga menerapkan Kurikulum 2013 maka guru PAI di sekolah tersebut harus memenuhi minimal 24 jam mengajar dalam satu minggu. Jika terdapat guru yang belum memenuhi jam tersebut, 
maka perlu diambil kebijakan untuk memenuhi jam mengajar guru tersebut.

Sesuai dengan Keputusan Menteri Agama nomor 103 tahun 2015 dan Peraturan Menteri Pendidikan dan Kebudayaan nomor 4 tahun 2015, untuk memenuhi jam mengajar seorang guru selain dengan menambah jam mengajar, dapat juga ditempuh dengan cara menjadi wakil kepala sekolah untuk tingkat sekolah menengah, menjadi kepala perpustakaan, menjadi pembina kesiswaan, menjadi wali kelas, mengisi ekstra kurikuler sekolah, dan menjadi guru piket.

Peneliti mengambil contoh keputusan dalam permasalahan ini adalah pemenuhan jam mengajar guru yang ditempuh dengan cara menambah jam mengajar di Satuan Administrasi Pangkalan (Satminkal) lain. Dalam hal ini keputusan yang diambil merupakan keputusan yang dihasilkan dari analisis informasi EMIS sebagai salah satu sarana dalam pengambilan keputusan.

Identifikasi masalah pemenuhan jam mengajar guru tersebut dapat diperoleh dari informasi berbagai sumber. Disamping dari perolehan analisis data EMIS, masalah tersebut juga dapat diketahui dari laporan guru yang bersangkutan terutama guru sertifikasi yang akan melakukan pencairan tunjangan profesi guru, laporan pengawas atau Unit Pelaksana Teknis (UPT) untuk SD, laporan kepala sekolah, dan catatan seksi PAI terhadap sekolah-sekolah yang menerapkan Kurikulum 2013 maupun Kurikulum Tingkat Satuan Pendidikan (KTSP). Setelah permasalahan ini ditemukan, kemudian Kepala Seksi PAI mengadakan musyawarah dengan pihak terkait dalam merumuskan alternatif pemecahan masalah.
Perumusan alternatif pemecahan masalah berkenaan dengan pemenuhan jam mengajar guru dilakukan dengan menganalisis data EMIS yang mencakup data sekolah-sekolah yang belum ada atau kekurangan Guru Pendidikan Agama Islam (GPAI). Adapun prosedurnya adalah mulai dari ditemukannya masalah, kemudian guru yang bersangkutan akan menghadap ke Kasi PAI untuk bermusyawarah dengan pengawas mengenai alternatif pemecahan masalahnya, selanjutnya atas rekomendasi Kasi PAI dilanjutkan dengan pengambilan informasi dari hasil analisis data EMIS mengenai sekolah-sekolah yang kekurangan GPAI. Setelah proses analisis dilakukan, maka dibuatlah keputusan bahwa guru yang bersangkutan dapat memenuhi jam mengajarnya di sekolahsekolah tertentu yang sudah dipilih berdasarkan analisis data EMIS.

Tahap selanjutnya adalah implementasi kebijakan yang telah diambil. Dalam implementasi ini ada beberapa prosedur yang harus dilakukan, yaitu setelah guru yang bersangkutan mendapatkan Surat Keterangan Pemenuhan Jam Mengajar sebagai rekomendasi mengajar ke sekolah tertentu, maka guru tersebut harus membuat nota kesepaham atau Memorandum of Understanding (MOU) antara satuan administrasi pangkalan (Satminkal) satu dengan Satminkal dua yang berisi kesepakatan untuk penambahan jam mengajar yang selanjutnya diserahkan kepada seksi PAI. Setelah MOU diterima dan diserahkan ke seksi PAI, maka kemudian Kementerian Agama Kabupaten Majalengka menerbitkan Surat Perintah Tugas (SPT) kepada guru yang bersangkutan untuk dapat segera mengajar di sekolah yang ditentukan. 
Evaluasi kebijakan secara umum di seksi PAI dilakukan pada tiap semester mengikuti pembaruan data EMIS. Namun untuk evaluasi implementasi keputusan pemenuhan jam mengajar yang telah dilaksanakan di lapangan merupakan tanggung jawab para pengawas. Apabila terdapat kendala dalam pelaksanaan kebijakannya di lapangan, maka pengawas langsung memberikan laporan ke seksi PAI untuk dianalisis kembali dan merumuskan keputusan yang baru. Sehingga kebijakan yang telah diterapkan dapat ditinjau kembali atas dasar kesesuaiannya dengan standar yang ada. Sebagaimana penjelasan dari Kasi PAI Kementerian Agama Kabupaten Majalengka sebagai berikut:

"Itu kita evaluasi semesteran, karena pada prinsipnya kan yang namanya EMIS itu kan di satu semester kan harus diupdate, dari situlah nanti termasuk kan mengevaluasi, ada ndak dari kebijakan ini yang masih belum memenuhi standar, kita evaluasi terus itu setiap, setiap satu semester".

Menurut peneliti, pemanfaatan EMIS dalam pengambilan keputusan di seksi PAI Kementerian Agama Kabupaten Majalengka sudah maksimal. Hal ini dibuktikan bahwa database EMIS dapat menyajikan berbagai macam informasi mengenai pendidikan khususnya di seksi PAI Kementerian Agama Kabupaten Majalengka. Oleh karena itu EMIS telah memberikan manfaat yang besar dalam perencanaan pendidikan, penyusunan anggaran, dan pengambilan keputusan.

Adapun kekurangan yang dimiliki adalah dalam penyajian data EMIS tiap semester masih membutuhkan waktu yang cukup lama, sehingga belum memberikan data yang tepat waktu. Jadi apabila di awal semester muncul suatu permasalahan, maka EMIS terbaru dalam satu semster tersebut belum mampu menyajikan data yang maksimal. Hal ini dikarenakan pembaruan data EMIS masih dalam proses pengumpulan. Namun jika permasalahan yang muncul sebatas pemenuhan jam mengajar, maka masih bisa dilihat dari data EMIS semester sebelunya. Karena sejatinya updating data EMIS tiap semester cenderung mengalami penambahan kolom data yang belum tercantum sebelumnya, sehingga sebagian besar data masih mengalami persamaan dengan data semester sebelumnya, kecuali data dalam kolom-kolom yang baru.

Dalam proses pengambilan keputusan berbasis EMIS, kasi PAI memiliki kecakapan dalam memanfaatkan sumber daya yang ada. Sehingga dalam memperoleh keputusan terbaik, kasi PAI tidak hanya mengandalkan pendektan personal dan komitmen terhadap peraturan saja, namun didukung dengan analisis data EMIS yang akurat dan diperkuat dengan faktor lain seperti kedisiplinan serta loyalitas staf dan pengawas.

\section{F. Kesimpulan}

Pengelolaan data EMIS di seksi PAI Kementerian agama Kabupaten Majalengka telah sesuai dengan prosedur yang telah ditentukan oleh operator EMIS pusat. Bahkan dalam pemenuhan kebutuhan organisasi internal seksi PAI, operator EMIS berinisiatif untuk mengembangkan pengelolaan data tersendiri di luar aplikasi EMIS yang ditentukan. Aplikasi EMIS mulai awal semester genap tahun 2015/2016 mengalami peningkatan yaitu adanya tambahan aplikasi EMIS berbasis on/ine. Dalam pengumpulan data EMIS, seksi PAI memiliki kendala dari beberapa guru yang tidak disiplin dalam mengumpulkan data 
sehingga memperlambat validasi datanya. Pengumpulan data emis yang terlalu lama berakibat tidak tersedianya data yang akurat dan tepat waktu sebagai pendukung pengambilan keputusan, sehingga apabila ada permasalahan di awal semester, EMIS belum dapat menyajikan informasi secara maksimal. Data EMIS dianalisis dan disajikan dalam bentuk excel sebagai informasi dalam pengambilan keputusan.

Proses pengambilan keputusan di seksi PAI Kementerian Agama Kabupaten Majalengka terdiri dari identifikasi masalah, perumusan alternatif pemecahan masalah, implementasi kebijakan, dan evaluasi kebijakan. Keputusan yang diambil diharapkan menjadi keputusan yang terbaik. Dalam hal ini kasi PAI selalu melakukan metode pendekatan dan selalu berkomitmen pada aturan yang ada, sehingga keputusan yang diambil dapat diterima oleh semua pihak.

Pemanfaatan EMIS dalam pengambilan keputusan di seksi PAI Kementerian Agama Kabupaten Majalengka sudah sesuai dengan tujuan diterapkannya aplikasi tersebut dalam membantu kegiatan manajemen pendidikan di lingkungan Kementerian Agama. Hal ini terlihat dari sebagian besar keputusan yang dirumuskan telah memanfaatkan data pendidikan islam yang terdapat dalam data base aplikasi EMIS sebagai informasi bahan analisis perumusan alternatif kebijakan seperti penentuan jumlah guru peserta sertifikasi, penyusunan anggaran, penyusunan program pendidikan, pemerataan dan pemenuhan jam mengajar guru, serta keputusan pendidikan lain yang memanfaatkan informasi EMIS. Data EMIS sangat menunjang pengambilan keputusan. Didukung dari kecakapan operator EMIS yang mampu menyajikan data secara maksimal dan kemampuan kepala seksi PAI dalam menggunakan metode pendekatan personal sehingga keputusan yang dihasilkan dari analisis data dan pendekatan personal merupakan keputusan yang terbaik dan dapat diterima oleh semua pihak.

\section{G. Daftar Pustaka}

Kurniadin, Didin dan Machali, Imam, Manajemen Pendidikan Konsep \& Prinsip Pengelolaan Pendidikan, Provinsi Jawa Barat: Ar-Ruzz Media, 2012.

O'Brien, James A. dan Marakas, George M., Sistem Informasi Manajemen;Management

Information Systems, Jakarta: Salemba Empat, 2014.

Peraturan Menteri Agama No. 13 Tahun 2012 tentang Organisasi dan Tata Kerja Instansi Vertikal Kementerian Agama. Anonim,

Rochaety, Eti, dkk. Sistem Informasi Manajemen Pendidikan, Jakarta: Bumi Aksara, 2009.

Rusdiana dan Irfan, Moch., Sistem Informasi Manajemen, Bandung: Pustaka Setia, 2014.

Syarip, Dodi Irawan dan Rosidin, Sistem Manajemen Data dan Informasi Pendidikan di Lingkungan Direktorat Jenderal Kelembagaan Agama Islam, Jakarta: Departemen Agama RI; Direktorat Jenderal Kelembagaan Agama Islam, 2003.

Winarno, Wing Wahyu, Sistem Informasi Mariajemen, Yogyakarta: UPP AMP YKPN, 2004. 